\title{
How does access to early childhood services affect the participation of women in the labour market?
}

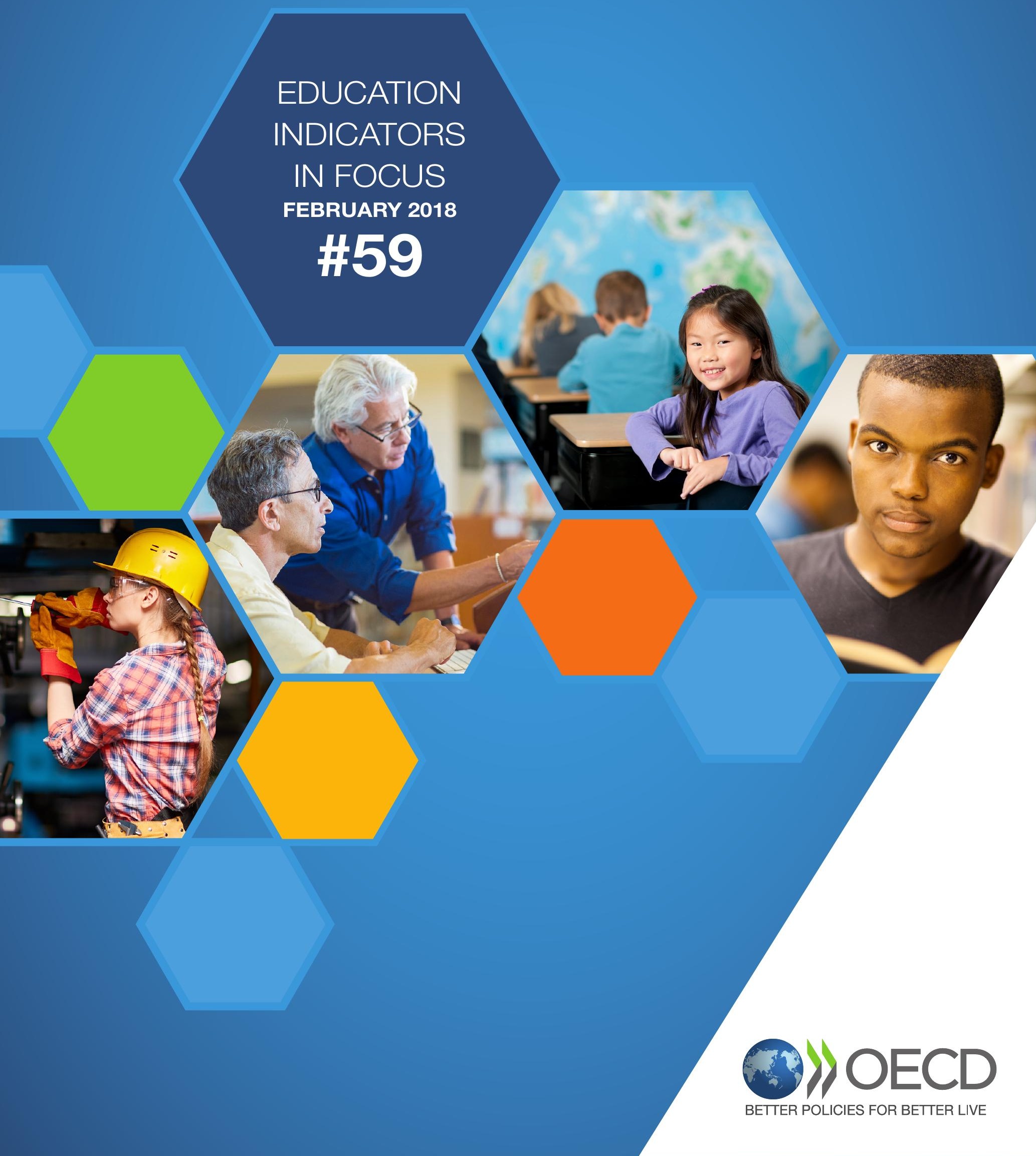




\section{How does access to early childhood services affect the participation of women in the labour market?}

- Women's labour force participation has increased significantly over the past 30 years. The rise in early childhood education and care (ECEC) provision over this period has greatly contributed to this change, particularly for mothers with children under the age of 3 .

- In spite of this increase, women are still three times more likely to work part time than men. Increasing the number of ECEC hours per week available to young children is paramount to increasing the full-time participation of mothers in the labour market.

- Participation in ECEC is not only important for women's employment. It also has positive effects on children's well-being, learning and development. However, in some countries, poorer families still face significant financial barriers to accessing these services. More efforts are needed to make ECEC services more affordable, especially for children under the age of 3.

\section{Women's labour force participation rates have increased substantially over the past decades}

The demographic landscape and family structures have changed dramatically in recent decades. Ageing populations, declining fertility rates and a greater proportion of children living in lone parent families in OECD countries are all part of these changes. An increasing share of young people now attain higher levels of education and then wait until one or both partners are securely established in their careers before having children (OECD, 2017a).

The likely long-term shrinkage of the working-age population - as well as the public benefits of having a greater proportion of tertiary-educated individuals in the workforce - means that countries increasingly need to ensure that the skills of both men and women are put to use in paid employment (OECD, 2012 and OECD, 2017b). Women's labour force participation rates have increased substantially in most countries since 1985, except among the youngest age group (20-24 year-olds), when many are still in education (Figure 1). On average across OECD countries, women's employment rates increased between 1985 and 2015 from 56\% to 73\% among 25-54 year-olds while men's employment rates have fallen slightly in most countries over the same period (OECD, 2017c).

FIGURE 1 / More women of childbearing age are in paid work than in the past

Employment rates of women in OECD countries, 1985-2015

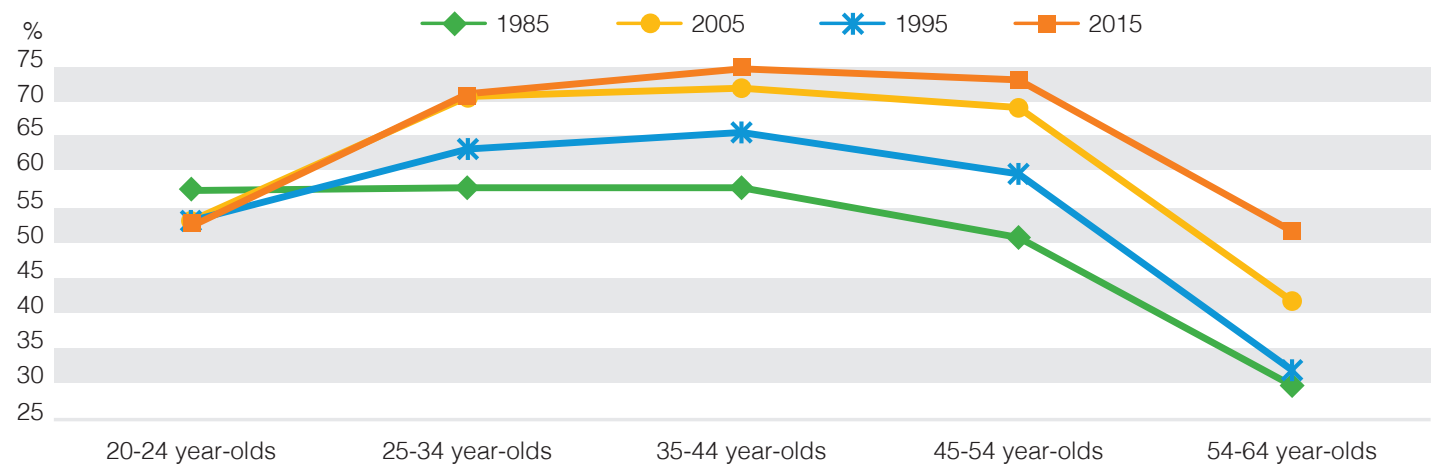

Source: OECD (2017c), Employment Database, www.oecd.org/employment/emp/onlineoecdemploymentdatabase.htm. 


\section{The rise in early childhood education and care provision is a key driver of women's labour market participation}

Current demographic and labour market patterns are a further motivation for governments to take early childhood education and care (ECEC) provision seriously. The rise of dual-income households brings the challenge of combining family constraints with involvement in paid work. The availability of quality ECEC services and other work-family provision give women greater opportunities to enter employment and start a family.

The share of children enrolled in ECEC services has been on the rise in all OECD countries for a couple of decades, both for children under 3 and for older children (OECD, 2017b). In addition, the concept of services for children under the age of 3 is progressively broadening. ECEC services are no longer just intended to help support working parents, but also to meet objectives such as early childhood development, gender equality, social integration and family support.

The availability of ECEC services is a key driver of women's labour market participation. The correlation between mothers' labour market participation and enrolment rates in ECEC is particularly strong for mothers whose youngest child is under 3 years old. The countries with the highest labour market participation rates (full time and part time) among mothers of young children, such as Denmark, Luxembourg, the Netherlands, Portugal, Slovenia and Switzerland, also have a high proportion of young children enrolled in ECEC (Figure 2). There is a similar correlation for mothers whose youngest child is between 3 and 5 years old, but it is weaker than for mothers of younger children.

In countries with low ECEC provision, such as Austria, the Czech Republic, Finland, Greece, Italy and Poland, the lack of availability of ECEC for the youngest children is compensated for by extensive use of informal childcare arrangements. These services are generally unregulated care arranged by the child's parent either in the child's home or elsewhere, provided by relatives, friends, neighbours, babysitters or nannies. With the exception of the Czech Republic, these countries also have aboveaverage employment rates of mothers. However, the quality of these services is subject to debate because carers may lack professional knowledge in some cases and because these childcare arrangements may not necessary offer children enough opportunities for social interaction with other children (OECD, 2011).

\section{Generous parental leave, if supported by adequate family policies, can have a positive effect on women's employment}

The availability of affordable ECEC services plays a key role in the increased labour force participation rates among women observed in most countries. However, other work-family provision - such as temporary withdrawal from the labour market through parental leave - also influences whether mothers have to choose between labour market participation and child rearing. The different family policies interact with one another, and if properly combined, are more efficient in promoting both women's employment and high quality ECEC. The positive effect of paid parental leave on women's employment depends greatly on the other family policy measures, the degree of employment protection in the country, and the willingness of fathers to pay a greater part in child rearing. Countries offering long leave periods but low cash benefits and limited ECEC services - such as Hungary or the Czech Republic- have low women's labour force participation. On the other hand, countries with a high take-up of parental leave by mothers, as well as generalised paternity leave and greater access to ECEC services for young children, tend to have greater gender equality in the labour market (Norway, Sweden, Iceland, Denmark) (OECD, 2017d).

\section{The number of hours per week children can attend early childhood education and care services greatly influences whether women work full or part time}

The general increase in both access to ECEC services and women's employment hides major differences across countries in the intensity with which both young children participate in ECEC, and women take part in the labour market. From a labour market perspective, the availability of full-day ECEC services is crucial for enabling parents of young children, especially mothers, to work full time and secure higher earnings and better career opportunities. 


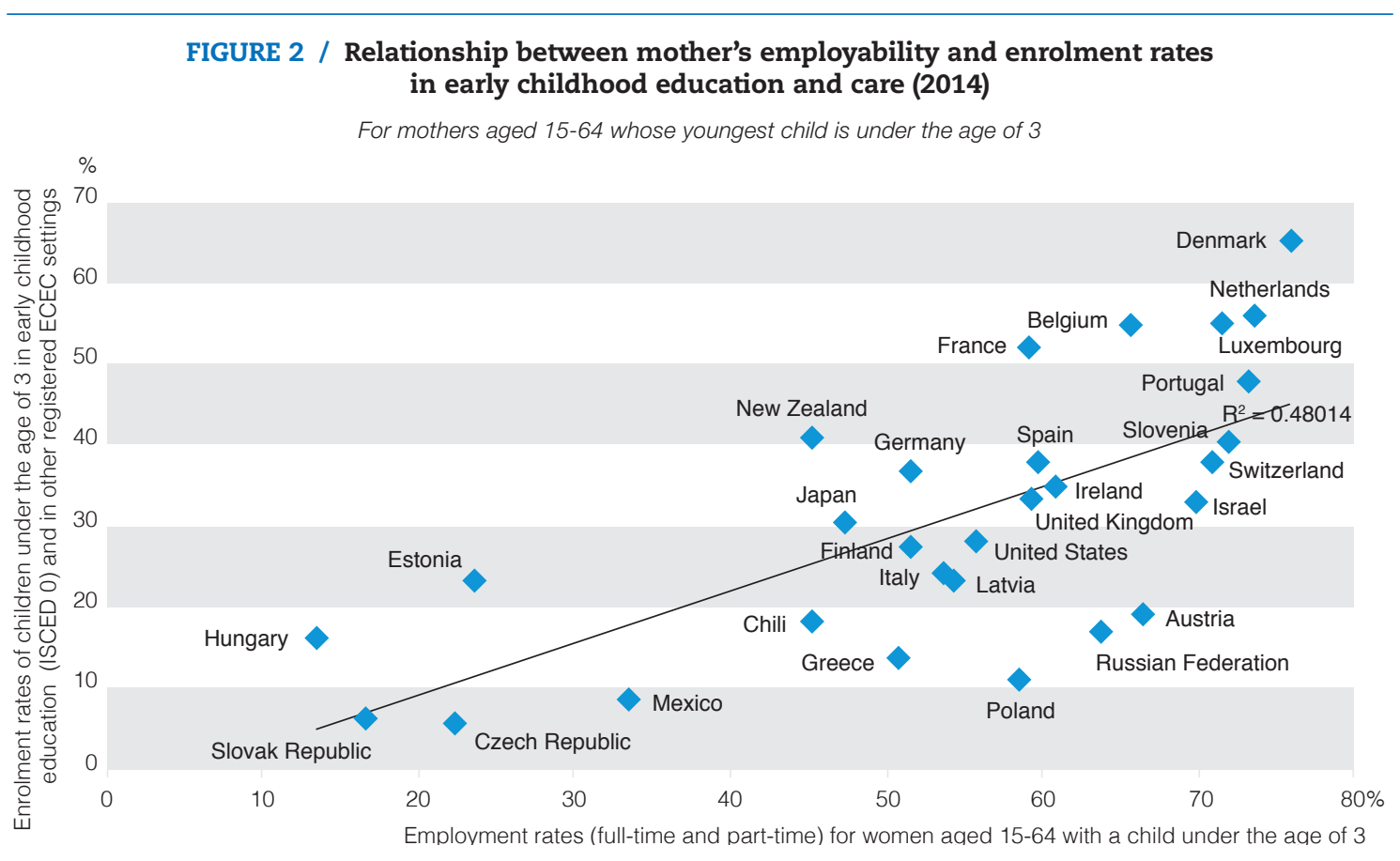

Source: OECD (2017a), Starting Strong 2017: Key OECD Indicators on Early Childhood Education and Care, http://dx.doi. org/10.1787/9789264276116-en; OECD (2017d), OECD Family Database, www.oecd.org/els/family/database.htm.

On average, women were still three times more likely to be in part-time work than men in 2015. While mothers' labour market participation is strongly associated with the availability of ECEC services, the number of hours per week children under the age of 3 attend ECEC services is highly correlated with the part-time employment rates of women with at least one child under 15. Countries with both high levels of participation in ECEC and greater intensity of participation (in hours per week) are in general those in which most mothers work full time. These include all the Nordic countries except Finland, and France, Luxembourg, Slovenia and Portugal. By contrast, in the Netherlands and New Zealand, an above-average proportion of children under the age of 3 attend ECEC, but for fewer hours per week. As a consequence, more than $40 \%$ of women with at least one child aged 0-14 are employed part time in these two countries (Figure 3).

FIGURE 3 / Relationship between the usual number of hours per week for which children under the age of 3 are enrolled in formal childcare and part-time employment (2014)

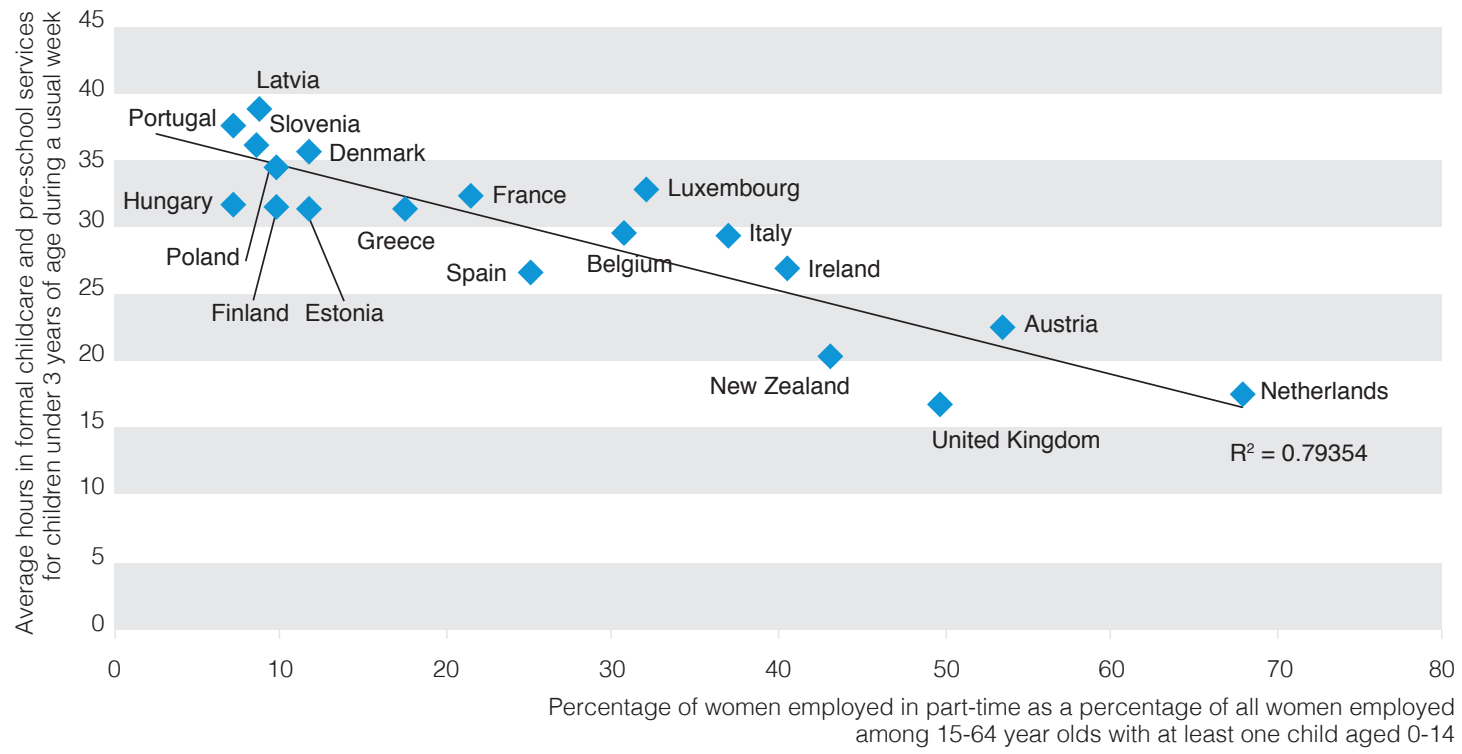

Source: OECD (2017a), Starting Strong 2017: Key OECD Indicators on Early Childhood Education and Care, http://dx.doi. org/10.1787/9789264276116-en; OECD (2017d), OECD Family Database, www.oecd.org/els/family/database.htm. 


\section{Children from poor families still face barriers to accessing early childhood education and care services and their mothers to entering the labour market}

As seen above, expanding access to ECEC and offering an adequate number of hours per week for young children boosts the full-time participation of women in the labour force. Accordingly, many countries have taken steps to increase access to ECEC services over the past decades. However, children from poorer families have traditionally faced greater barriers in accessing ECEC services. Even now, in most countries, children under 3 are more likely to use ECEC when they come from relatively advantaged socio-economic backgrounds or when their mother has completed tertiary education. This is not surprising because mothers with higher levels of educational attainment are more likely to face higher opportunity costs when staying at home; they are also most likely to have better jobs and higher earnings and so can pay ECEC fees more easily (OECD, 2011). For example, in Austria, the participation rate for children whose mother has attained tertiary education is 31\%, 20 percentage points higher than for children whose mother has not (11\%) (OECD, 2017d).

Affordability is thus a key driver of equity in ECEC. The share of private funding tends to be higher for very young children than for those enrolled in pre-primary education (ISCED 02). On average, public sources cover $69 \%$ of total expenditure on early childhood educational development (ISCED 01), but this rises to $83 \%$ for pre-primary education (ISCED 02), (OECD, 2017b). The typical gross childcare fee paid by the parents for two children (aged 2 and 3) enrolled in full-time ECEC settings is around $27 \%$ of the average wage.

However, governments often provide various schemes to help reduce the net financial burden for families including cash transfers, rebates and tax reductions. In this context, lone parents and lowerincome families are often entitled to additional financial support. On average across OECD countries, the net cost of childcare (for two children aged 2 and 3 in full-time ECEC settings) for a full-time employed single parent who earns half the average wage works out at $10.7 \%$ of average earnings - not far off half that for two-income couple with two children of the same age (OECD, 2017d and Figure 4).

FIGURE 4 / Gross and net childcare costs for two children aged 2 and 3 attending full-time care at a typical childcare centre (2015)

$\%$ of average earnings

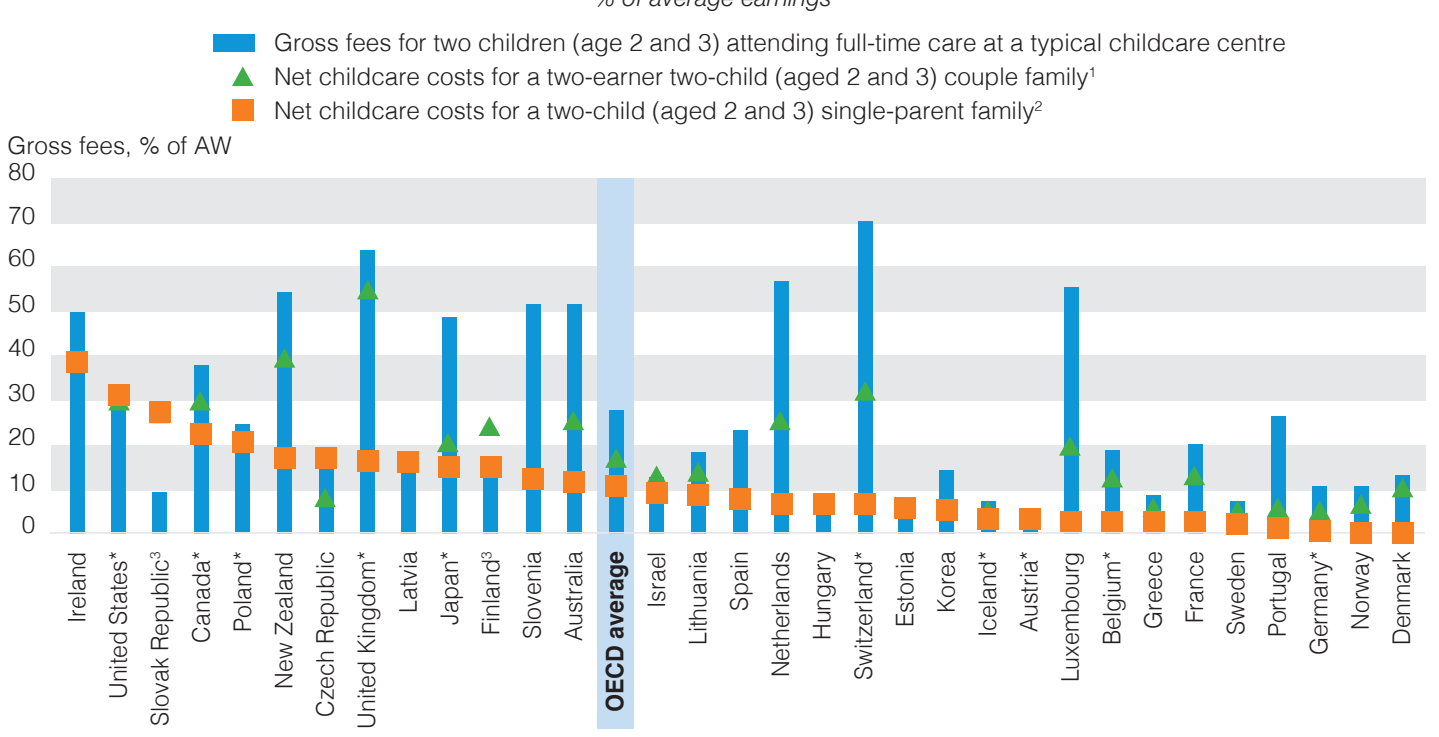

Note: Data for countries marked with an * are based on estimates for a specific region or city, rather than for the country as a whole. Average earnings/the average wage (AW) refers to the gross wage earnings paid to average workers, before deductions of any kind (e.g. withholding tax, income tax, private or social security contributions and union dues). The net childcare cost represents the difference between the cost incurred by a family that uses ECEC services and an otherwise identical family that does not.

1. Gross earnings for the first earner in the family are set at $100 \%$ of average earnings (AW), and for the second earner at $67 \%$ of average earnings. Both partners are assumed to be working full-time.

2. Gross earnings for the single-parent set at $50 \%$ of average earnings. The single parent is assumed to be working full-time.

3. The net "cost" of childcare is inflated by the loss of the parental allowance once children are no longer cared for at home.

Source: OECD (2017e), Tax and Benefit Models, http://www.oecd.org/els/benefits-and-wages.htm; OECD (2017d), OECD Family Database, www.oecd.org/els/family/database.htm. 
Net childcare costs for full-time employed single parents are low in countries where gross fees are already relatively low, and also in countries where parental fees are largely publicly subsidised. By contrast, they remain high, at more than 20\% of average earnings, in Canada, Ireland and the United States, which have no or relatively low targeted benefits, and also in the Slovak Republic, where the net "cost" of childcare is inflated by the loss of the parental allowance once children are no longer cared for at home (OECD, 2017d and Figure 4).

\section{The bottom line}

While the benefits of early childhood education and care (ECEC) services to better learning are now widely acknowledged, a widespread and accessible provision for these services also helps support gender equality in the workforce. In particular, the availability, intensity, reliability and affordability of ECEC play an important role in engaging women full time in the labour market. While ECEC has experienced a surge of policy attention over the last decades, wide variations still exist across countries and its costs remains a barrier to accessing paid work for poor families and lone parents, mostly mothers. More efforts are needed to increase the provision and accessibility of free ECEC services, especially for children under the age of 3.

\section{FOR MORE INFORMATION:}

OECD (2017a), Starting Strong 2017: Key OECD Indicators on Early Childhood Education and Care, OECD Publishing, Paris, http://dx.doi.org/10.1787/9789264276116-en.

OECD (2017b), Education at a Glance 2017: OECD Indicators, OECD Publishing, Paris, http://dx.doi.org/10.1787/ eag-2017-en.

OECD (2017c), Employment Database, OECD, Paris, www.oecd.org/employment/emp/ onlineoecdemploymentdatabase.htm.

OECD (2017d), OECD Family Database, OECD, Paris, www.oecd.org/els/family/database.htm.

OECD (2017e), Tax and Benefit models, OECD, Paris, http://www.oecd.org/els/benefits-and-wages.htm.

OECD (2012) Meeting of the OECD Council at Ministerial Level (Paris, 23-24 May 2012), Gender Equality in Education, Employment and Entrepreneurship: Final Report to the MCM 2012, https://www.oecd.org/employment/50423364.pdf. OECD (2011), Doing Better for Families, OECD Publishing, Paris, http://dx.doi.org/10.1787/9789264098732-en. OECD (2006), Starting Strong II: Early Childhood Education and Care, OECD Publishing, Paris, http://dx.doi. org/10.1787/9789264035461-en.

Teaching in Focus

\section{CONTACT:}

Axelle Magnier (axelle.magnier@oecd.org),

Eric Charbonnier (eric.charbonnier@oecd.org)

Photo credit: @ Christopher Futcher / iStock; @ Marc Romanelli / Gettyimages; @ michaeljung / Shutterstock; @ Pressmaster / Shutterstock This work is published under the responsibility of the Secretary-General of the OECD. The opinions expressed and arguments employed herein do not necessarily reflect the official views of OECD member countries.

This document, as well as any data and any map included herein, are without prejudice to the status of or sovereignty over any territory, to the delimitation of international frontiers and boundaries and to the name of any territory, city or area.

The statistical data for Israel are supplied by and are under the responsibility of the relevant Israeli authorities. The use of such data by the OECD is without prejudice to the status of the Golan Heights, East Jerusalem and Israeli settlements in the West Bank under the terms of international law. 